\title{
THE EVOLUTION \\ OF A PROFESSION
}

\author{
Paper presented at the symposium \\ Is a professional Association the answer?
}

\section{CHARLOTTE SEARLE}

\section{OPSOMMING}

Die begrip professie het ontstaan toe geneeshere, prokureurs, onderwysers en ander geleerdes in die kerkdiens georden moes wees. Hulke het bely (profess) voordat hulle die besondere diens kon lewer. Later het sekulêre groepe vir die verskillende beroepe ontstaan in die vorm van gildes, gevolg deur kwalifiserende verenigings in die 19de eeu. Uit hierdie organisasies het die kern konsepte ontwikkel wat as kriteria vir professionalisme dien. Die opvatting dat universiteitsopleiding en privaatpraktyk kriteria vir professionalisme is, het eers later ontstaan en is ongeldig in die lig van bogenoemde.

In Suid-Afrika voldoen verpleging aan die kriteria vir professionalisme. Dit beteken egter nie dat elke verpleegkundige se optrede professioneel is nie. Baie aanvaar nie hulle professionele verantwoordelikhede, soos verantwoordbaarheid vir hulle eie optrede nie. Die funksionele taaktoewysing wat in baie hospitale steeds voortbestaan negeer ook die professionele model.

Die verpleegkundige moet aangemoedig word om professioneel te wees in die wyse waarop sy haar rol vertolk en die beeld wat sy voorhou.

\section{THE ORIGIN OF PROFES- SIONS}

The word profession derives from the Latin profiteri - to make an open or public statement of one's beliefs and intentions, one's acknowledgement of a certain fact. In the modern sense the word has come to describe collectively the nature of an occupation, the practice of which requires certain advanced preparation in some liberal art or applied science. The practice is characterised by some form of exclusiveness (such as only those who are qualified in a certain area of study may practise the profession), by commitment, and by observances of an ethical nature.

The concept of a profession is copied from the medieval guilds in which the members of the various highly skilled trades bonded together to formulate and uphold high standards, to train neophytes in the particular craft, to socialise these learners into a brotherhood, and to protect their members. As the early learned occupations developed, they formed societies and associations which eventually fulfilled the same type of role as a medieval guild. They professed cer- tain levels of knowledge, certain skills and certain beliefs, and in time became known as professionals.

Millerson says: Of all sociological ideas, one of the most difficult to analyse satisfactorily, is the concept of a profession. (Millerson, 1964 p.1) He believes this is due to semantic confusion, structural limitations arising out of attempts to describe universal fundamental characteristics of a profession, and the slavish adherence to a static model, rather than the appreciation of the dynamic process involved in professionalism (Millerson, 1964 p.1). This is the crux of the situation.

\section{THE EVOLUTION OF A PRO- FESSION}

Let us look at how professions evolve, and let us then examine the nursing profession in South Africa against this backdrop.

Prior to the 13th Century, anyone wishing to be a physician, lawyer. secretary, surveyor, architect, teacher or diplomat, had to take Holy Orders, that is, he had to join the Church. He professed. (Millerson,
1964, p.16) Gradually, after the dissolution of the monasteries ( 1536 to 1539) this practice disappeared. Law was the first secular profession to be organised. The medical proFession remained unorganised up to about the 16th Century when certain guilds for physicians and for surgeons were established. It remained only superficially organised up to the middle of the 19th Century, only a few years before Florence Nightingale started her life's work.

The most notable and spectacular developments came in the 19th Century with the rise of the qualifying associations. Professionalization, as a process, diffused through many occupations by means of the Qualifying Association. This type of association demonstrated an ability to convert occupations into professions. (Millerson, 1964, p.25) They organised the members of the particular occupation. provided training courses and conducted examinations so that a certain identifiable mark of quality was attached to the practitioners. The underlying concepts were

- the need to ensure professional conformity 
- the maintenance and development of standards

- the elimination of competition

- the need to improve the status of the members.

To this end certain core professional concepts were developed namely that

- the profession provides a service for the public and that this enjoys precedence at all times

- the proficiency of members has to be based on certain identifiable skills, attitudes and a body of theoretical knowledge. Competence has to be tested by means of examinations

- the members have to subscribe to a code of conduct and of ethical norms and values

- the profession is clearly identifiable, which means that its practitioners profess a distinct specialised service and the public must recognise it as such.

This was the position at the turn of the 20th Century. The Victorian era that encompassed most of the 19 th Century and the early part of the 20th Century, saw the hey-day of capitalism - the free enterprise system, in Britain and her colonies, Europe and the United States of America. This was the era of great individual capitalists who founded enormous industrial empires, and this was the era of the private general medical practitioner. So we find that a new dimension is added to the concept of professionalism. namely that the professional person is autoromous and is engaged in his own practice. Flexner in the USA stressed this concept, because America at that time was one of the major strongholds of the free enterprise system, which it still is, and which naturally influences the position of the American nurse on professionalism. At the same time the drive for widespread university education developed in America, so that in contrast to the qualifying association approach in Great Britain, the university education approach was postulated in the United States. Much has been said in American literature about the fact that all nurses do not have a university education, and do not control their own practice, that is, are not in private practice, and hence cannot be regarded as professionals.

This standpoint is rejerted on the basis that a university digree is not the only criterium for admission to a profession in Westerı Europe and Britain where membership of the prestigious qualifvirg associations have greater status than university degrees. Moreovar, hundreds of thousands of proessionals including learned judges are salaried employees. Flexner propounded his theories before the mass advent of socialism. If the rremise is correct that private practice is an essential criterium for profsssionalism, then all lawyers, doctors, engineers, architects and the like in socialist and communist countries and all salaried professionals in other countries are deprived of their professional status at a stroke of the pen.

In other profess ons, who are not so concerned abot the validity of their professional status as nurses appear to be, there is a tendency to accept that the term profession ought to be applied freely to anyone able to demonstrats a high standard of examined competence, experience, achieved responsibility and good education. IMillerson, 1964, p.212) Many accest Ward Darley's point of view that the truly professional person is one who, by virtue of intellectual capacity, education and moral outlook, is capable of the exercise of intelletual and moral judgement at a high level of responsibility. (Darley, 1971, p.83) He makes the point that judgement is based on broad knowledge, penetrating wisdom ajout the particular circumstances and a great moral certitude about one's actions.

\section{THE SOUTH AFRICAN CON- TEXT}

A sketch of the development of the profession of nursing in South Africa, would be too lengthy so this discussion is confined to the criteria forming the conceptual framework of professionalism for nursing in South Africa. It can be described as follows

- the specialised knowledge and skills pertaining to the profession of nursing are based on a broad foundation of theoretical knowledge. This theoretical know- ledge is drawn from

- the sciences basic to medicine (the biological, physical, medical and social sciences)

- the age-old accumulation of empirical knowledge about the instrumental and expressive functions of the nurse at any point along the continuum of health care

- the legal and ethical foundations on which practice of the profession rests

- the specialised function it fulfils in society

- the expertise known as nursing is based on a clearly defined and well-organised body of knowledge, with a controlled system of educating and training the neophyte

- the aspirant to professional status must prove his competence by submitting proof of the education he has undergone for the purpose and must successfully complete a professional examination. That part of the examination dealing with practising the profession and with the synthesis of all the knowledge that culminates in professional acts must be conducted by members of that profession

- the professional integrity of the practitioner is regulated by enforcing the observance of an ethical code and of the norms of his peer-group as well as those of society. The protection of society is a paramount feature in such norms and ethics

- the designation of registered (professional) nurse is a temporary one, which can be removed from the holder under certain circumstances. A nurse whose name is removed from the register for any reason whatsoever, either for voluntary or disciplinary reasons or for non-payment of registration fees, may not use the title of registered nurse, neither may she practise nursing for gain in any capacity whatsoever. This would constitute a criminal offence

- the service rendered by the professional nurse must relate to the welfare of the community. This must at all times take precedence when decisions in regard to the practise of the profession have to 
be made. (This does not mean that the public can exploit the professional practitioner). It must recognise the dignity and rights of others

- a professional nurse is held accountable for her actions both to the law and to her peer-group (the other members of the profession as embodied in the South African Nursing Council). This, of course, also applies to other categories of nurses

- the professional nursing group is an organised group in the community with a common goal

- the members of the nursing profession show subconscious as well as conscious awareness of identity with other members of the group. They are an in-group

- there is a substantial level of uniformity in the way in which the members of the group view the final objectives of their role (nurse-clinicians, nurse-administrators, nurse-teachers and nurse-researchers all have one final end in view for their service - better health care for the people of their country and for others beyond the borders of their country seeking their care)

- the norms and ethics of the group are developed by the group

- the profession is subjectively recognised by its own members and legally by Parliament, because the public is willing to accept the occupation as a profession. Because of its importance to the community, the public granted it -cognition and status and, at the same time, desired to control it. It recognised the status of the profession by vesting this control in the profession itself. The profession is also recognised by other professions and is mentioned in a variety of Acts of Parliament dealing with health legislation as a profession with special duties

- there is an obvious sentiment that the professional nurse belongs to an exclusive group that must meet the high standards of practice. Only those who have complied with the standards of admision are admitted to the group

- the menbers of the profession have prescribed means of admitting new nembers to the profession. Once the member has been accepted into the group she is expected to otserve the norms and ethics of the group and to assume special respossibilities towards colleagues, clients, patients, and the public at large

- as a return forthis observance of the group norms, the member may obtain , protected title. wear certain irsignia and use certain letters ater her name; all this ensures a certain status

- the recognitiol of the group as a profession by the law has resulted in the celegation of rights and privileges to the group; in the use of the services of the group to the axclusion of others who wish to render the service: in official recogntion as a separate service group in requests for advice from the group; and in awards of special status symbols, titles and honours

- the profession has a strong professional association to organise and develop; to act as the voice of the profession; to ensure professional standards; to regularise the approach to the problems of the practice of the profession; to act as watchdog over the progress of the law, regulations and administrative aspects as a matter of public duty; to advise on the systematising of training, the rationalising of selection, and the forming of a basis for development within the profession itself

- the profession is controlled by the profession itself, under delegated responsioility from Parliament through he South African Nursing Counsil, in respect of the critical elements of professionalism, namely: prescribing admission standards, education. and syllabi, approving and inspecting nursing schools, examining competencs; registering and prescribing the regulations relating to professional practice, and disciplinary control. The South African Nursing Council like the South African Medical and Dental Council is one of the sub- ordinate legislative authorities of the country which prescribes professional practice requirements.

Whilst the above criteria establish that nursing in South Africa as a corporate entity warrants the recognition Parliament has bestowed on it in the Nursing Act, it must be said that nursing, like teaching, social work and the paramedical occupations, is in varying stages of development in many countries. The status of women, educational background of entrants to these professions, the social origins of the members, society's need for a particular service and numerous social and legal constraints all affect the evolution of professions. The author is the first to admit that nursing does not warrant the designation profession universally, but she, like so many lawyers and sociologists in South Africa, has no doubt about its full professional status in this country.

\section{PROFESSIONALISM}

Having stated that nursing as a corporate entity in South Africa is a profession, the question must be raised as to whether all nurses are professional? Being a profession, and having all members acting as professionals are not necessarily synonomous. It has been made clear that the idea that professionalism requires private practice is outmoded. This concept negates the professional concept in socialist countries and in situations where the person is in salaried employment, be he minister of the church. doctor, lawyer, architect, engineer and the like. In the context of world developments in the 20th Century the concept of being in charge of one's own practice can be interpreted in a different way. Here lies the crunch. Of course every registered nurse in South Africa is in charge of her own practice. Not a private fee-for-service practice but a practice in the everyday health team situation where she, and she only, accepts personal responsibility and remains accountable for all her actions. Only she can decide whether she is able to or should carry out a particular aspect of nursing. She is accountable for how she relates to other team members, how in a joint 
responsibility with the doctor she will share in the patient's diagnosis and treatment and accept responsibility for care. When she accepts a patient into her charge, she becomes jointly responsible for him with the doctor. She controls her practice in relation to this patient. Neither she, nor the doctor is an autonomous practitioner for such a practitioner does not exist, both are responsible to the patient, their registration authority and the law of the land. They are accountable and if one is accountable, one cannot be autonomous! She is therefore solely responsible for her own practice whether this is in a fee-for-service situation or in a salaried situation where she has to accept responsibility for a number of patients simultaneously. This is the basis of her professional practice in South Africa she is accountable for her practice and her decisions.

Here in South Africa there is no limit to what the nurse may do as a nurse such as there is in countries dominated by trade unions. Circumstances, social need, the conscience, the knowledge, the skills and the accountability of the nurse. and above all the immediate needs of the patient, must decide what she shall do and where, how and when she shall do it. In every one of these aspects she is held accountable.

But how many registered nurses accept their responsibility in this way? How many of them have turned themselves into the handmaiden of the doctor? If you feel nursing is not a profession there is a screw loose somewhere. You are not being a professional in the way the law permits you to be one. Let us take another point - are there not some nurses who see the climbing of the administrative ladder more important than clinical nursing, the core of our professionalism? The fact that a different uniform is worn once one enters the administrative nursing hierarchy shows that administration and teaching are considered as being more important than clinical nursing.
The functional assignments so beloved in many institutions indicate that there are nurses who are not thinking professionally, they are thinking about things and jobs, not about the person-to-person total responsibility that is inherent in a professional practice situation. Does functional assignment not denote a factory-floor approach rather than a professional approach? In a crisis the professional responsibility is to ensure the greatest good for the greatest number and functional assignments then have a place in nursing, but still, the nurse's professional role and responsibilities are denigrated to the level of the factory-floor. It is not implied that factories are unimportant - only that their methods are industrial to suit their ends. Nursing is professional to meet the needs of human beings - the patients. Functional nursing is an industrial model, not a professional model.

Quality patient care cannot be achieved, nor can those who have fallen by the wayside in the professional handling of their practice see themselves in charge of their own professional practice unless nurse leaders reprofessionalise nursing practice wherever the industrial model has penetrated. If they ensure that nurses use the concepts of the nursing process (or scientific method approach), and that such modalities of nursing care as patient allocation, team nursing or even primary nursing are practised; if they cut down on some of their regulations which tells the nurse all the time what she has to do; if they encourage the individual registered nurses to make their own decisions, to recognise that they are joint partners with the doctor in the care of the patient, with an equal level of accountability, whilst respecting his leadership role; if they ensure that nurses know that personal professional practice and personal accountability legally takes place in every nursing situation in our country; the younger members of the profession will not need to doubt, as some in- evitably do now, whether they are professionals in the deepest and richest meaning of the word. Have they not professed their knowledge and skill of nursing, their belief in the meaning of this important occupation and their commitment to its cause when they took the pledge of Service at the Lamp Ceremony? What has gone wrong, and how do we put it right? Should every registered nurse not commit herself anew by reprofessionalising her practice by accepting a one-to-one relationship with her patients, by providing individualised care for which she is accountable and by epitomising the concept of the early professions? The professional practitioner is a gentleman or a lady in the widest sense of the word, she is one who has professed, who has made an open or public statement of her beliefs and intentions as a nurse. Her public statement can now be described as the way she enacts her role as a nurse - what sort of role model she is, how members of the multi-disciplinary health team, the patient and public, the student nurse and fellow nurse practitioners see her. In fact does she project an image of a professed nurse? This is the crux of the whole issue!

Peterences and General Bibliography

Millerson, F The qualifying associations Routledge \& Kegan Paul London 1964

Darley, W The professions and professional people Nursing Forum I 196]

Towle. Charlotte The learner in education for the professions University of Chicago Press Chicago 1954 Strauss, S A; Strydom, M J Die Suid-Afrikaanse Geneeskundige Reg Van Schaik Beperk Pretoria 197 The British Nursing Record Volume I April 1, 1888 Bernard. J: Thompson. L Sociology - nurses and their patients in modern society C V Mosby St Louis 1966

Searle, C Testimony to fifty years of service 1914-1904 SANA Pretoria 1964

The Medical and Pharmacy Act, 1891 (Act 34 of 1891) (Re gistration of Medical Practitioners, Apothecaries, Dentists, Chemists and Druggists, Midwives and Nurses)

The Nursing Act, 1944 (Act 45 of 1944)

The Nursing ACI, 1978 (Act 50 of 1978.) as amended

The Medical, Dental and Supplementary Health Service Pro fessions Act 1974. (Act 56 of 1974), as amended 